\title{
Internal and external analysis
}

Case: Markkinointi Pakkaset Oy

Tia-Maria Pakkanen

Degree Thesis 


\begin{tabular}{|c|c|}
\hline \multicolumn{2}{|l|}{ DEGREE THESIS } \\
\hline \multicolumn{2}{|l|}{ Arcada } \\
\hline Degree Programme: & International Business \\
\hline \multicolumn{2}{|l|}{ Identification number: } \\
\hline Author: & Tia-Maria Pakkanen \\
\hline \multicolumn{2}{|l|}{ Title: } \\
\hline Supervisor (Arcada): & Sveinn Eldon \\
\hline Commissioned by: & Markkinointi Pakkaset Oy \\
\hline \multicolumn{2}{|c|}{$\begin{array}{l}\text { This thesis was commissioned by Markkinointi Pakkaset Oy, owner of five } \\
\text { HTH Kitchenforum showrooms in Helsinki, Vantaa, Lahti, Lappeenranta and Kouvola. } \\
\text { The thesis objective was to investigate the internal and external environments of the case } \\
\text { company, find the factors affecting the company's performance and competitiveness and } \\
\text { to make strategic recommendations based on these findings, in order to improve the com- } \\
\text { pany's competitiveness. }\end{array}$} \\
\hline \multirow{3}{*}{\multicolumn{2}{|c|}{$\begin{array}{l}\text { This research is significant to the company, as research to this extent has not been con- } \\
\text { ducted before. During the last two years the case company has been implementing a sig- } \\
\text { nificant expansion strategy and, therefore, there have been big changes in the company's } \\
\text { internal and external environments. It is essential for companies to analyze its environ- } \\
\text { ments regularly and reassess the direction of its business, in order to further develop its } \\
\text { business. This thesis aims at finding solutions to following questions: What is the current } \\
\text { state of the case company's internal and external environment? What strategic recom- } \\
\text { mendations can be made to the company based on these findings? } \\
\text { Literature in strategic management was used as the theoretical framework. The theories } \\
\text { of value chain, competitive advantage and core competencies were used as the main theo- } \\
\text { ries. The qualitative research method was used as the thesis research approach. The quali- } \\
\text { tative method was chosen as the objective was to find new perspectives and ideas for the } \\
\text { company and to get a deeper understanding about researched phenomena. Empirical re- } \\
\text { search was carried out through individual interviews. Interview questions were divided in } \\
\text { four main categories. Interview questions were recorded and transcribed. } \\
\text { Interviews produced a number of beneficial information to the company. This infor- } \\
\text { mation will help the company to reinforce and develop its business. }\end{array}$}} \\
\hline & \\
\hline & \\
\hline Keywords: & $\begin{array}{l}\text { Strategic management, internal and external environment, } \\
\text { value chain, core competency, SWOT analysis }\end{array}$ \\
\hline Number of pages: & 61 \\
\hline Language: & English \\
\hline Date of acceptance: & \\
\hline
\end{tabular}




\begin{tabular}{|c|c|}
\hline \multicolumn{2}{|l|}{ OPINNÄYTETYÖ } \\
\hline \multicolumn{2}{|l|}{ Arcada } \\
\hline Koulutusohjelma: & International Business \\
\hline \multicolumn{2}{|l|}{ Tunnistenumero: } \\
\hline Tekijä: & Tia-Maria Pakkanen \\
\hline \multicolumn{2}{|l|}{ Työn nimi: } \\
\hline Työn ohjaaja (Arcada): & Sveinn Eldon \\
\hline Toimeksiantaja: & Markkinointi Pakkaset Oy \\
\hline \multicolumn{2}{|c|}{$\begin{array}{l}\text { Tämän opinnäytetyön toimeksiantajana toimii Markkinointi Pakkaset Oy, joka omistaa } \\
\text { viisi HTH Keittiöforum myymälää Helsingissä, Vantaalla, Lahdessa, Lappeenrannassa ja } \\
\text { Kouvolassa. Yritys toimii Suomen suurimpana HTH Keittiöforum -merkin jälleenmy- } \\
\text { jänä. Opinnäytetyö tehtiin tilaustyönä. }\end{array}$} \\
\hline \multirow{2}{*}{\multicolumn{2}{|c|}{$\begin{array}{l}\text { Opinnäytetyön tavoitteena oli analysoida yrityksen sisäistä ja ulkoista toimintaympäris- } \\
\text { töä sekä löytää mahdollisia kehityskohtia SWOT analyysin pohjalta tarkoituksena yri- } \\
\text { tyksen kilpailukyvyn parantaminen. Tutkimus on merkityksellinen toimeksiantajalle, sil- } \\
\text { lä tämän kaltaista tutkimusta ei ole aiemmin suoritettu. Tutkimuksen merkityksellisyyttä } \\
\text { lisää myös yrityksen suuri laajentuminen, jonka vuoksi yrityksen sisäinen ja ulkoinen } \\
\text { ympäristö on kokenut muutoksia. Tutkimuskysymykset ovat: Minkälainen on yrityksen } \\
\text { nykyisen sisäisen ja ulkoisen toimintaympäristön tila? Minkälaisia strategisia suosituksia } \\
\text { voidaan tehdä löydettyjen tulosten pohjalta? } \\
\text { Tutkimuksen teoreettinen viitekehys muodostettiin strategisen johtamisen kirjallisuutta } \\
\text { käyttäen. Teoreettinen viitekehys rajattiin käyttäen viiden kilpailuvoiman, arvoketjun, } \\
\text { ydinosaamisen ja kilpailuedun teorioita. Tutkimuksen empiirinen osuus toteutettiin kva- } \\
\text { litatiivista tutkimusmenetelmää käyttämällä. Kvalitatiivinen tutkimusmenetelmä valit- } \\
\text { tiin, koska tutkimuksella haluttiin löytää uusia ideoita ja näkökulmia sekä saada syvem- } \\
\text { pää ymmärrystä tutkittavasta aiheesta. Haastattelut suoritettiin yksilöllisinä haastattelui- } \\
\text { na. Haastattelut jaettiin neljään aiheeseen, jonka perusteella tehtiin SWOT-analyysi. } \\
\text { Kaikki haastattelut nauhoitettiin ja litteroitiin. }\end{array}$}} \\
\hline & \\
\hline Avainsanat: & $\begin{array}{l}\text { Strateginen johtaminen, sisäinen ja ulkoinen } \\
\text { toimintaympäristö, arvoketju, ydinosaaminen, SWOT } \\
\text { analyysi }\end{array}$ \\
\hline Sivumäärä: & 61 \\
\hline Kieli: & Englanti \\
\hline Hyväksymispäivämäärä & \\
\hline
\end{tabular}




\section{TABLE OF CONTENTS}

1 INTRODUCTION 6

1.1 Research questions 8

1.2 Thesis structure 8

1.3 Thesis background 9

$\begin{array}{lll}1.4 & \text { Research problem and objectives } & 10\end{array}$

1.5 Case company: Markkinointi Pakkaset Oy 10

2 THEORY 12

2.1 Strategic management 12

2.2 External environment 12

$\begin{array}{lll}2.2 .1 & \text { Five Forces } & 13\end{array}$

$\begin{array}{lll}2.3 & \text { Internal environment } & 14\end{array}$

$\begin{array}{lll}\text { 2.3.1 Competitive advantage } & 15\end{array}$

$\begin{array}{lll}\text { 2.3.2 Value chain } & 17\end{array}$

$\begin{array}{lll}2.3 .3 \quad \text { Value system } & 19\end{array}$

$\begin{array}{lll}\text { 2.3.4 Core competency } & 21\end{array}$

2.4 SWOT analysis 23

$3 \quad$ RESEARCH METHODS $\quad 25$

3.1 Data description 25

3.2 Data collection 26

$\begin{array}{lll}3.3 & \text { Interview form } & 27\end{array}$

$\begin{array}{lll}3.4 & \text { Data processing } & 28\end{array}$

$\begin{array}{lll}3.5 & \text { Reliability and validity } & 28\end{array}$

4 RESEARCH RESULTS

4.1 Questions regarding company strengths 32

4.2 Questions regarding company weaknesses 35

$\begin{array}{lll}4.3 & \text { Questions regarding company opportunities } & 37\end{array}$

4.4 Questions regarding company threats 40

4.5 SWOT analysis 42

5 DISCUSSION AND FINDINGS 45 
6 CONCLUSION

REFERENCES

59

APPENDICES

60

Appendix 1

Letter to respondents

Appendix 2

Interview form

Appendix 3

Interview transcriptions 


\section{INTRODUCTION}

An organisations environment will be constantly changing and globalisation will be increasing, which will set challenges for companies to remain and succeed in business. Therefore, every organisation has a need for change and development whether companies want it or not. As the world is getting smaller and competition is increasing, organisations have increasing pressure to develop its business, emphasize this knowledge and to strengthen its competitiveness. Strategic thinking and strategic management are relevant topics as they are currently on the lips of all managers in the organisations in order to achieve competitive advantage, high performance and to success and remain in business.

The most significant and successful strategic management theories are mostly less than 40 years old, which implies that strategic management is a relevant topic in today's business world. There are several approaches on this topic from Igor Ansoff's views about environmental turbulence in the 1960's and 1970's, Michael Porter's competitive strategies in the 1980's and Hamel and Prahalad's views in the 1990's on strategies regarding future competitiveness. These strategic approaches highlight how environments affect companies and, therefore, these factors have to be taken into account when formulating strategies. (Kamensky 2000 p. 16).

In this thesis Markkinointi Pakkaset Oy's internal and external environments will be investigated and analysed. The aim of this thesis is to identify the company's strengths and weaknesses and the opportunities and threats of the company's external environment. Based on these findings the author will provide strategic recommendations and suggestions on how the company could use and improve its strengths and weaknesses and exploit its opportunities and be pre-pared for external threats. Most companies are not fully aware their current resources and capabilities, therefore, all resources and opportunities are not been utilized. The case company has been expanding its business considerably during the past two years; therefore, it is necessary to analyse the current and future environment. The thesis objective is to provide the 
case company development ideas and strategic recommendation based on these findings.

The author was provided an opportunity to do research for the case company, where the author did her practical training. After practical training the author was provided full-time position in the team tasked with planning and implementing the company's expansion plans and to assist in marketing. The author has obtained an interest in strategic management and general management. This research is unique for the case company, as this kind of research has not been conducted before. The CEO of the case company has asked the author to hold a presentation describing the research results and the strategic suggestions to the whole company. The CEO regards this research as essential for the overall success of company.

Qualitative research was used as the thesis research approach. The author conducted individual interviews with 6 respondents, who have been in close cooperation with the case company for many years and have wide knowledge about the case company, the overall industry and the competition. Semi-structured questions were used in the interviews, which enabled the author to ask further questions and enable respondents to give deeper analysis about phenomena. All interviews were recorded and afterwards transcribed. 


\subsection{Research questions}

The aim of this thesis is to find solutions to following questions:

- What is the current state of the case company's internal and external environment?

- What strategic recommendations can be made to the company based on these findings?

\section{$1.2 \quad$ Thesis structure}

This thesis has been formulated according to the instruction of Arcada's Thesis Guide and it will be divided into theoretical and empirical parts. The thesis will start with presenting the theoretical framework of the thesis, including different acknowledged theories about the researched phenomena. The research methods chapter will follow the theoretical part. The empirical part of the thesis will be presented in the last part. The theory part will consist of different theories about strategic management, including the concepts of strategic management, internal and external environments, competitive advantage, core competencies and SWOT analysis. These theories will show how the company is constantly being affected by different factors that have to be managed and taken into consideration when making strategic decisions and in order to be competitive.

In the research methods chapter, the author will present and specify the research methods used and will indicate arguments supporting the chosen decisions. The author will explain how the information was collected and how the participants were selected. In this chapter the author will present how the collected data was processed and in the end, the author will evaluate the reliability and validity of research. The research results are presented under the chapter called research results. In the chapter 
called discussion, the author will analyse and give strategic recommendations and suggestions for the case company.

\subsection{Thesis background}

The case company has been implementing its expansion strategy during the last two years, which has resulted in opening two new showrooms. The expansion strategy has resulted in many changes in the organisation, for example, an increase in the number of employees, facilities, and showrooms. There is a need in all organisations to analyse its internal and external environments to be able to identify how the company has been succeeding, what it could do better and to identify the barriers to the organisation's operations in the future. Due to the company's expansion, coupled with the current economical situation, it is a good time to evaluate the company's resources to ensure the future growth, profitability and competitiveness of the company.

The current economical situation is affecting the overall economy and it has a strong effect on the industry where the case company is operating. Addition to this, the industry is extremely competitive, making it essential to know how to competitive in the market.

According to strategic management theories, companies should regularly construct different analysis about their environments, especially if there have been changes within organisations or industry. It is essential that organisations know what are the current situations inside the company and in its external environment in order to predict the future crisises and exploit opportunities. The world is changing every minute, requiring companies to change as well and needing up to date analysis. 


\subsection{Research problem and objectives}

This thesis aims at finding out strengths and weaknesses of the case company and opportunities that the company could exploit to be more competitive and identify the threats the company might face in the future.

The aim of this research is to bring new development ideas and strategic recommendations for the company and to discover results about the company's internal and external environment that company has not been aware. According to strategic management theories, companies should regularly construct different analysis about the company, especially if there have been changes within the organisation or industry.

\subsection{Case company: Markkinointi Pakkaset Oy}

Markkinointi Pakkaset Oy is family-owned company founded in 1982 which currently employs 17 employees full-time and provides direct income for 8 sole traders. The company's turnover was 5,1 million Euros in the year 2011 (Balance Consulting 2012). The company is the major dealer for the HTH Kitchenforum brand in the Finnish market owning showrooms in Helsinki, Vantaa, Lahti, Kouvola and Lappeenranta. Markkinointi Pakkaset Oy is responsible for marketing and selling HTH Kitchenforum products in the capital region and South-eastern Finland. The company has been dealer for the HTH kitchen brand since it started in 1982 and has been the longest brand dealer in Finland. The company has been expanding its business in 2011 by opening Lahti and Vantaa showrooms. Due to these expansions the amount of employees has grown from 10 to 17 employees.

The HTH Kitchenforum brand is represented in 12 different countries with more than 130 showrooms. The brand has its main concentration and activity in the Northern part of Europe. HTH Kitchenforum is the largest kitchen supplier in Denmark and has great market share in Norway and Sweden. Finland is the smallest market from 
all the Northern countries. There are currently 7 showrooms in Finland. In all countries the inspired showrooms are owned by individual dealers or by factory. All the showrooms, regardless of the ownership, are run across the counties by the respect for the same philosophies and concepts. The philosophy 'It must be possible to do it better' is still the key driver for HTH Kitchenforum.

Two skilled craftsman brothers Hans Henning and Tony Haahr established HTH Kitchenforum in 1966 in Olgod, Denmark. They had been working for other kitchen suppliers and they were unimpressed by their gained experiences. After working closely with other kitchen manufacturers they thought 'It must be possible to do it better', which since has been the philosophy of HTH Kitchens.

Addition to the mission of being the leading kitchen manufacturer in Northern Europe, HTH Kitchenforum has another ambitious goal; to have the most satisfied customers in Northern Europe. This statement demands a lot from the brand and from the dealers across Northern Europe.

HTH Kitchen is part of the listed Swedish Nobia Group, which is the largest manufacturer in Europe. HTH plays an important role within Nobia Group, as HTH is one of the leading kitchen manufacturers in Northern Europe. The philosophy 'It must be possible to do it better' still remains the underlying mission, therefore HTH is the leading brand for innovation and development within Nobia Group. 


\section{THEORY}

\subsection{Strategic management}

The main objective for a company is to perform well compared to rival firms. Why some companies are performing better than its competitors and why some companies can achieve continuous success and some not, are the fundamental questions in the field of strategic management. Strategic management has essential an effect on a firm's performance and according to studies; organizations that are involved with strategic management tend to have higher level of performance. High level of performance can enable a company to achieve sustainable competitive advantage compared to competing firms. Strategic management is a combination of a firm's integrated decisions and actions aiming at achieving a strategic position through competitive advantage and above-rate returns. Strategic position can be achieved through successful strategy formulation and implementation. In order to form strategy, companies have to make a fundamental analysis of the firm's external and internal environments. A company can determine and form their strategy based on the analysis of company's external and internal environments. (Coulter 2008 pp. 4-5).

In this theoretical framework external and internal environments will be explored more in detail.

\subsection{External environment}

External environments comprises of factors existing outside the organisation. Regardless the industry, these factors will have enormous effect on any firm's growth and survival. Firms have to be aware of the conditions in its external environment and firms have to identify and understand the most significant threats and opportunities in its external environment that influences the company. External environments consist of many different factors comprising an enormous entity, including political, 
sociological, demographical, global and technological factors, customer preference and related industries factors, to name a few. External environments can be divided into three major areas including general, industry and competitor environments. (Lynch 2006 pp. 78-81).

\subsubsection{Five Forces}

Michael Porter has developed a method to analyse a firm's external environment. This method is called the Five Forces Model and it has been developed based on industry environment aspect. According to the model, a firm will be confronted with five different forces that will impact the firm's competitiveness. These forces are threat of new entrants, bargaining power of suppliers, bargaining power of buyers, threat of substitute products and rivalry among competing firms. (Lindroos \& Lohivesi 2006 pp. 219-220).

The five forces model is an important template to help firms determine whether the industry is attractive and has potential to earn above-average returns. According to Hitt et al. (2007 pp. 49-53), the industry is unattractive and there are small chances to achieve competitive position, if there are low entry barriers, buyers and supplier have strong bargaining power, there exists intense rivalry among competitors and there will be strong competitive threat of product substitutes. Firms should be aware of all these forces when they are planning their strategies and considering industries to enter. 


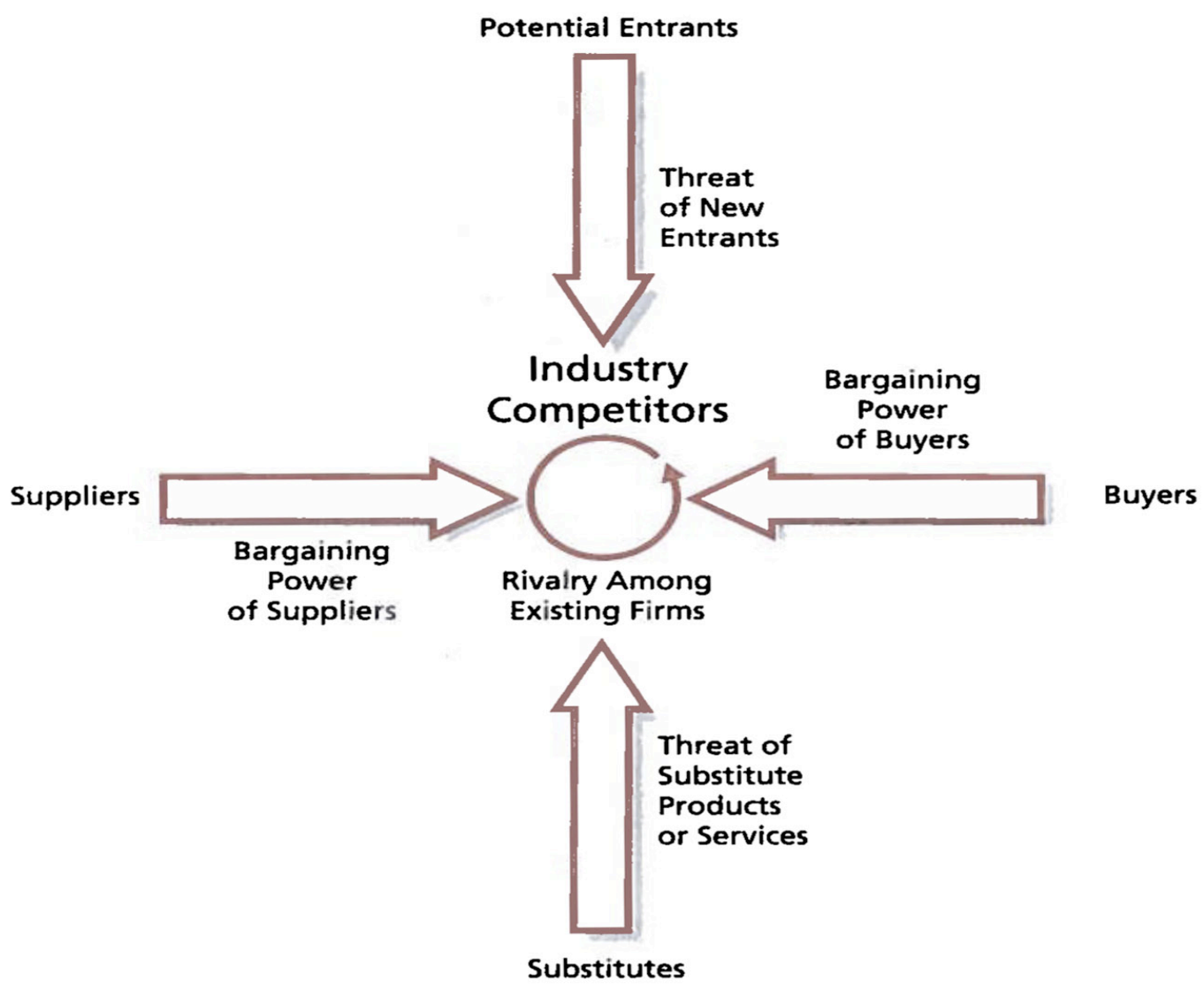

Figure 1. Five Forces model (Coulter 2008 p.74)

\subsection{Internal environment}

The internal environment contains factors that have influence on a company's resources. According to Hitt et al. (2007 p.71), "The resources are the sources of capabilities, some of which lead to development of the firm's core competences or its competitive advantage". Internal and external environments have to meet each other in the way that the firm can build a strategy that can lead to competitive advantage and above-average earnings. External environments can create opportunities and threats for a firm but internal environmental conditions can turn these opportunities and threats to competitive advantage by using the organisation's capabilities, unique resources and core competencies. Internal environment focuses on the firm's capabil- 
ities and core competencies, which can be identified and understood by using concepts of value chain and core competencies. (Hitt et al. 2007 pp.70-72).

\subsubsection{Competitive advantage}

The most important objective of the firm is to build and implement a strategy that will generate a competitive advantage. Barney describes competitive advantage: "A firm has a competitive advantage when it is able to create more economic value than rival firms. Economic value is simply the difference between the perceived benefits gained by a customer who purchases a firm's products or services and the full economic cost of these products and services. Thus, the size of a firm's competitive advantage is the difference between the economic value a firm is able to create and the economic value its rivals are able to create" (Barney 2007 p.17).

Companies are ultimately aiming to achieve sustainable competitive advantage, which enables companies to succeed in the long run. Michael Porter argues that a company can generate competitive advantage in two different ways, either through differentiation or cost advantage. According to Porter's definition, differentiation means the capability to provide customers superior and special value in the form of product's special features and quality or in the form of aftersales customer service. As a result of differentiation, company can demand higher price for its products or services. A company will earn higher profits due to differentiation in case the expenses will stay comparable to the costs of competitors. (Porter 2006 pp.74-77).

A company can gain competitive advantage through cost advantage. It can be gained if the company can have an edge to its competitors in producing products or services with lower costs. When a company has lower costs, it has the possibility to design, produce and market the products in a more efficient way, even though the products would be substitutable. Due to a cost advantage company can gain superior profits compared to competitors. (Zimmerer \& Scarborough 2002 pp. 86-87). 


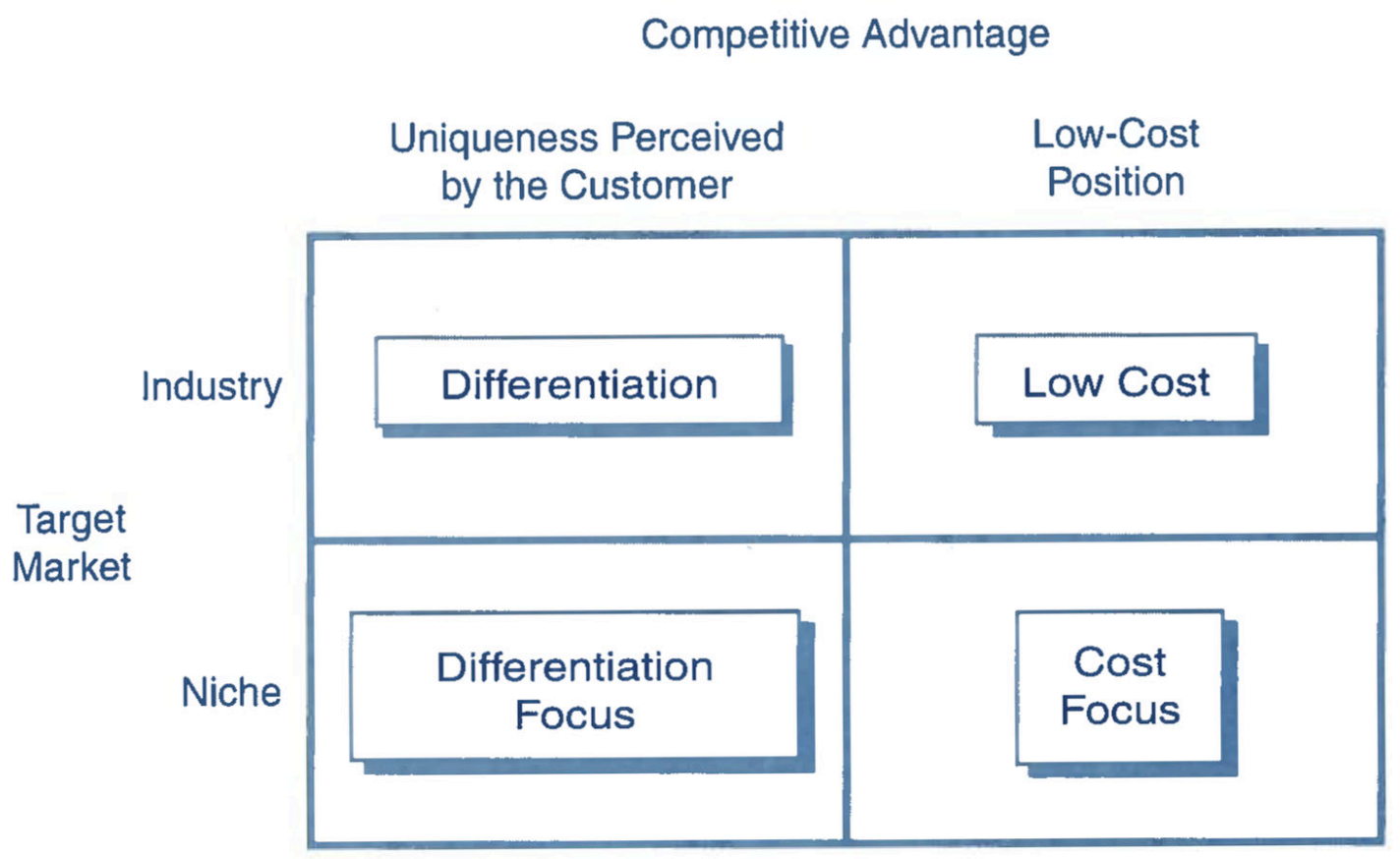

Figure 2. Competitive advantage (Zimmerer \& Scarborough 2002 p. 87)

Competitive advantage cannot be well comprehended if the company is viewed as an entity. The above-mentioned differentiation and cost advantage will affect a company's ability to achieve competitive advantage, but there are many different organizational functions that will influence whether a company can achieve cost advantage or differentiation advantage. Therefore, a company cannot be regarded as an entity; instead organizations' have many functions that competitive advantage is based on. Michael Porter has invented the concept of value chain to explore closer different functions of the organisations and those functions mutual interactions. Value chain provides an excellent tool to examine the origins of competitive advantage. It will divide organisations into two different strategically important groups, namely, primary activities and supporting activities, which can help to comprehend the potential sources for differentiation and to understand an organisation's costs behaviour. (Porter 1985 pp. 51-57). 


\subsubsection{Value chain}

All organisations have different organisational functions. These separate functions will be used when firm products or services are designed, produced, advertised and delivered to final customers and functions that will support the final product in many different ways. The organisations value chain is based on these different functions that help a product to move along the chain passing different stages starting from raw material stage to final customer stage. Every part of the value chain will increase the value of the final product. (Porter 1985 pp.54-60).

Value chain analysis is a great tool for companies to comprehend the parts of its operations that will create value and to understand the parts that are not equally as important in creating value. It is critical for companies to have knowledge about the essential parts of its organisation that are the key components enabling the company to succeed and be profitable. Value chain analysis can help firms to understand and to identify the key functions and their cost position. In order to identify the key functions, the value chain has been divided into two groups, primary activities that are the basic fundamental sources for the company and supporting activities that will support the primary activities. (Hitt et al. 2007 pp. 85-88).

Primary activities consist of five different basic areas including inbound logistics, operations, outbound logistics, marketing and sales. These basic activities will be found in all industries. Regarding the industry and the organisation's strategy, basic functions can be further divided into more specific functions. Inbound logistics is the first stage of the value chain. It will include functions regarding material handling, inventory control, warehousing, receiving and storing inputs used in production. The second stage in value chain is operations. This stage will include activities dealing with converting inputs into the final product form and will utilize the activities provided by inbound logistics. Outbound logistics is the third stage. These activities are involved with collecting and storing products and physically distributing the final products to customers. Material handling, order processing and timing are examples 
of these activities. The fourth stage is marketing and sales. These activities will concentrate on introducing products to customers, this can be done through advertising as well as preparing and launching marketing campaigns to make products attractive to customers. Sales force has an essential role here to promote products and make sales. The final stage is service, which is dealing with the aftersales service. The main objective for service stage is to maintain the product's value or to enhance it. Providing a range of services including installation, training or repair service can maintain or improve the value of the final product or service. (Lynch 2006 pp.202204)

Supporting activities will support the above-mentioned primary activities and will help to improve the primary activities' effectiveness and efficiency. Supporting activities can be divided into four main areas that can be further specified into more details influenced by the attributes to a specific industry. Four main areas are procurement, technological development, human resource management and company infrastructure. Procurement is activities concerning the sources for inputs, for example negotiating with material suppliers. Improvement of procurement activities can have a great affect on the costs and the quality of inputs. Technological development is involved with the group of activities that will try to improve products and the overall process. Technological development occurs in different forms in all firms and it can be used in any stage of the value chain. Technological development plays a significant role in achieving competitive advantage in all industries, in some industries it is crucial in order to survive in the market. Human resource management will effect an employees motivation and skills and the expenses of training, hiring and recruiting. Through effective human resource management, a company can gain a competitive advantage. Company infrastructure will be diverted from the other supporting activities, as it will support the whole value chain rather than any particular function. Company infrastructure will cover areas of general management, finance, accounting, planning, legal support and governmental relations. (Porter 1985 pp. 59$63)$. 
The value chain

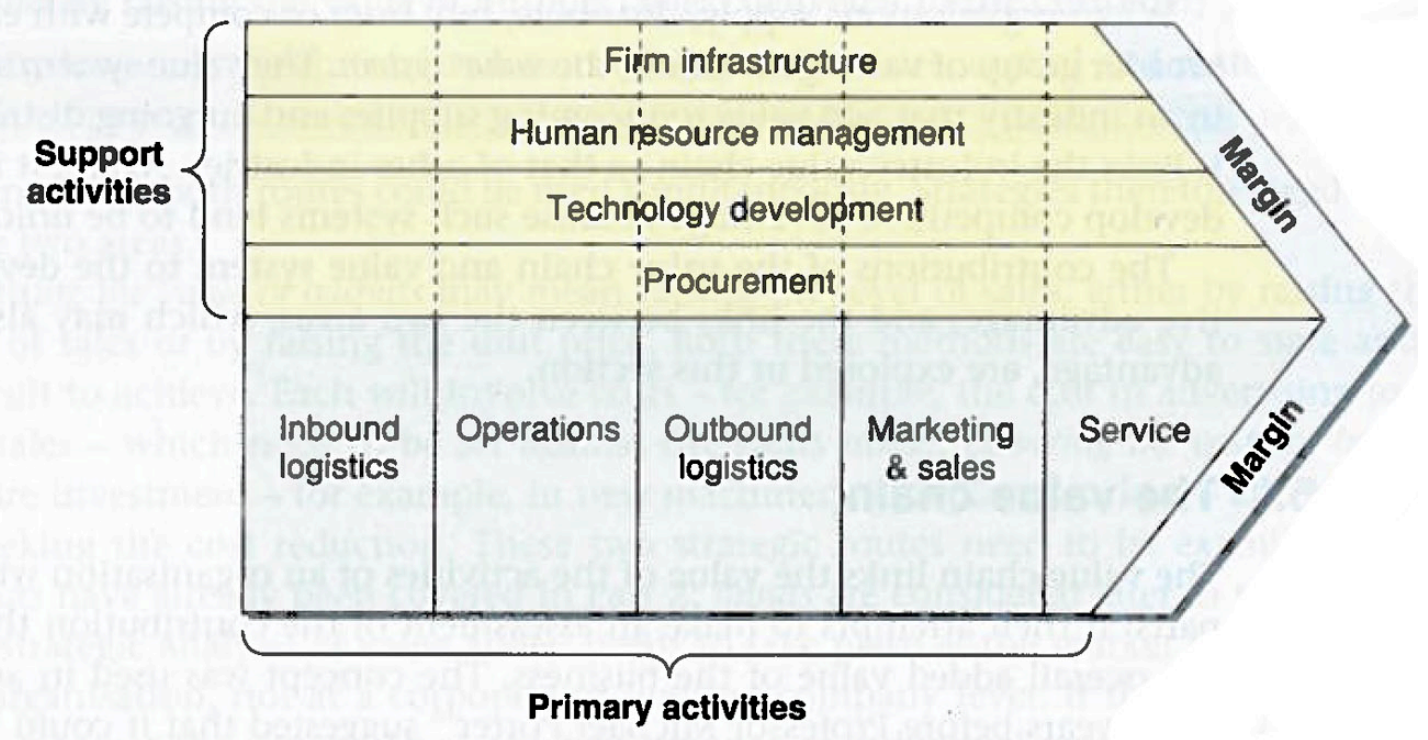

Figure 3. The value chain (Lynch 2006 p. 204)

\subsubsection{Value system}

An organisation's value chain is part of a more extended value chain, which is called the value system. The value system is an integration of supplier's, firm's, distribution channels and the buyer's value chains. Porter describes the linkages between different value chains as vertical integration. These linkages behave in a similar way as the different functions inside an organisation; therefore, all value chains in the value system have an influence on the organisation's costs and differentiation. For instance, suppliers will produce products or service and a firm will use them in its own value chain. When suppliers deliver goods regularly and punctually, the company does not need to invest in big storage facilities, which enables it to have lower costs. Products will continue through the distribution channel's value chain until it reaches the buyer's value chain. The distribution channel can cover many firm's own functions, for instance, the promotion and advertising. The linkages between different value chains can benefit both parties involved and generate an opportunity to improve competitive advantage. Linkages between value chains are not a zero-sum-game, instead the ob- 
jective is that all parties would benefit from cooperation and they could evolve together benefiting from each other.

Because a firm's value chain is part of a bigger value system, an organization's competitive advantage is not only dependable on its own functions. Instead, it is dependable also on the success of the whole value system and how the end customer perceives the entire value system, not only the value chain that the company contributes. (Porter 1985 pp. 70-73).

The value system

(a) Single-industry firm

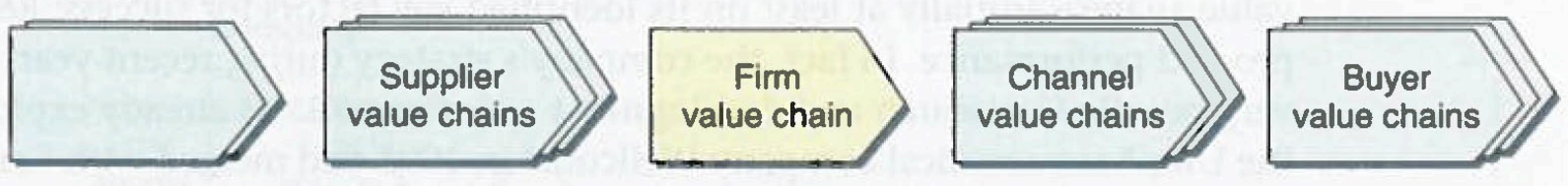

(b) Diversifled firm (with severai different business units, each with its own value chain)

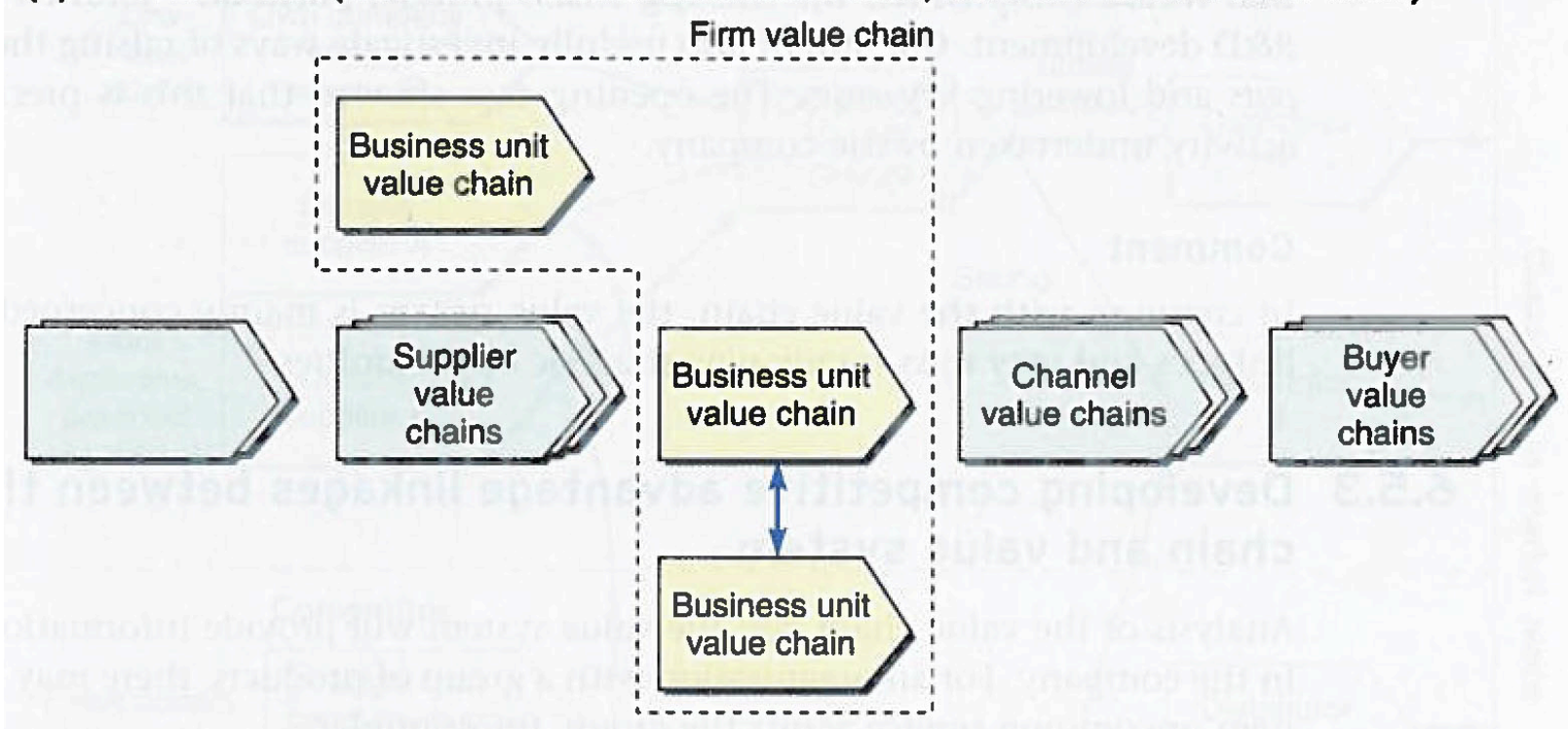

Figure 4. The value system (Lynch 2006 p. 205) 


\subsubsection{Core competency}

C.K. Prahalad and Gary Hamel have advocated a concept of core competency, which is a widely used concept in management theories. Prahalad and Hamel define core competency as the collective learning in the organization, especially coordinating diverse production skills and integrating multiple streams of technologies (Barney \& Hesterley 2008 p.218). An organization's combination of technological and managerial know-how, wisdom and experience are a complex set of capabilities and resources that can lead to a competitive advantage compared to a competitor.

There exists confusion about the definition of core competencies. Competency is defined as a combination of skills and techniques rather than individual skill or separate technique. For core competencies it is characteristic to have combination of skills and techniques, which makes the whole organization utilize these several separate individual capabilities. Therefore, core competencies cannot be built on one capability or single technological know-how, instead, it has to be the integration of many resources. The optimal way to define core competence is to consider it as sum of 515 areas of developed expertise. This frame of definitions can be hard for many leaders to define, as they have to perceive facts realistically in order to point out which really are core competencies and which are only the skills behind competences. (Hamel \& Prahalad 2006 pp. 255-257).

As mentioned above, there cannot be too many skills to be regarded as core competence as leaders cannot regard all the skills equally essential to the company. Therefore they have to have knowledge about the key areas of expertise that are critical to the company in the long run. Thus, major core competencies are identified in three areas. In order to regard particular skill or technology as core competence, it has to meet three areas including customer value, application to other markets and competitor differentiation.

Competitor differentiation is one of the main three conditions. The company can consider having a core competence if the competence is unique and it is difficult for 
competitors to imitate. This can provide a company an edge compared to competitors. It allows the company to provide better products or services to market with no fear that competitors can copy it. The company has to keep on improving these skills in order to sustain its competitive position. Competence does not necessarily have to exist within one company in order to define as core competence. Although all companies operating in the same market would have the equal skills and resources, if one company can perform this significantly better; the company has obtained a core competence. That's why it is important to differentiate between the substantial competence and the basic competence needed to operate in the certain line of activities. (Hamel \& Prahalad 2006 pp. 256-258).

The second condition to be met is customer value. When purchasing a product or service it has to deliver a fundamental benefit for the end customer in order to be a core competence. It will include all the skills needed to provide fundamental benefits. The service or the product has to have real impact on the customer as the reason to choose to purchase them. If customer has chosen the company without this impact, then competence is not a core competence and it will not affect the company's market position. (Hamel \& Prahalad 2006 pp. 258-259).

In order for a competence to be a core competence, it has to meet the requirements of the third condition as well. This last condition refers to application to other markets. As stated in the beginning when defining concept of core competences, it was argued core competence must be applicable to whole organization; it cannot be only one particular skill or specified area of expertise. Therefore, although some special capability would be essential or crucial for the success of some business activity, it will not be core competence if it is not fundamental from the whole organization's point of view and those skills cannot be removed from the particular group into creation of new services or products. It can be core competence if it can open up another potential markets to be exploited. (Hamel \& Prahalad 2006 p. 259). 
If the three above-mentioned conditions are met, then the company can regard it competence as core competency. Companies have to remember that core competences are not seen as fixed, therefore, they need constant evolving over the time and they have to change in the same cycle with the company's environment and opportunities to sustain the competitive position in the market.

\section{$2.4 \quad$ SWOT analysis}

SWOT analysis is a method to analyse a company's strengths, weaknesses, opportunities and threats. It will combine a company's internal and external environments. SWOT analysis has been developed for business contexts but it can equally be used for any other decision-making situations, which makes it one of the most known analysis methods. The basic idea behind the analysis is simple and it is seemingly easy to construct. SWOT-analysis can help companies to uncover new potential opportunities, identify inner competencies that companies have when compared to their competitors and identify internal weakness and external threats that should be minimized or avoided in order to be competitive. (Kamensky 2000 p. 171).

Strengths and weaknesses are assets and factors in a company's internal environment and they are related to the present time. Opportunities and threats are assets and factors in a company's external environment and they have future aspect. Strengths contain factors from the inner perspective of the company. These factors can be, for instance, personnel, reputation, organizational climate, organizational structure to name a few. It consists of the characteristics that make a company good at something, the advantages that the company has over its competitors and the things in which the company has succeeded. The aim of the SWOT analysis is to find strengths of the company and try to take advantages of these assets and further strengthen them. Weaknesses consist of factors that can affect a company's competitive advantage or disadvantage. Weaknesses found on the analysis should be avoided or removed. Not all weaknesses can be 
replaced but they should be improved in order to reduce their negative affect, otherwise weaknesses can lead to competitive disadvantage. (Kehusmaa 2010 p. 72).

Opportunities and threats present factors in an organization's external environment. These factors are forces that organizations cannot control, but in order to be successful they have to be aware of them. Companies have to be awake and constantly observe conditions in its environment to seize opportunities and to discover threats. Opportunities arise when organizations can become profitable from the exploitation of opportunities and benefit from these conditions in its environment. Companies can get an edge over its competitors by exploiting these opportunities; therefore, companies should strive for taking the greatest possible advantage out of opportunities. On the other hand, while exploiting opportunities, a company should try to minimize and avoid threats in its external environment. If a company is not prepared for these conditions, it can, in the worse scenario, jeopardize the whole business. Therefore, companies should be prepared to tackle these external threats so that they will not come as a surprise and then it can be too late to react. (Hitt et al. 2007 pp. 37-38).

There are some limitations to SWOT analysis. The typical causes for limitations can be that real criticism is not wanted or dared to express, or a company cannot address phenomena objectively or company has too wide aspect to approach phenomena. As a result, the real benefit cannot be gained, as the provided information is too common and vague. Another cause can be that there is no factual knowledge about the company, the environment or research phenomena. (Kamensky 2000 p.171). 


\section{RESEARCH METHODS}

A qualitative research method was used as the thesis approach. The qualitative method was chosen because the qualitative approach can provide deeper and more realistic understanding of research phenomena than would be obtained from purely quantitative data. The aim of the research is to find and reveal new perspectives and facts about research problem rather than to demonstrate existing assumptions. A qualitative approach was applied for the thesis as the research phenomena is not well known and more deeper and detailed understanding of the phenomena is acquired, therefore, the qualitative approach can produce diverse, rich and unexpected results. Six respondents were chosen to interview, which provides sufficient amount of data to collect and to be qualified as qualitative research. (Silverman 2005 pp. 7-10).

\subsection{Data description}

All respondents are important partners for the case company. Respondents were chosen because they have a vast knowledge and important information about the industry and they have been in cooperation with the case company and other companies in the industry for a long time. They have essential knowledge about the company and other companies in the industry. According to Tuomi \& Sarajärvi (2002 p. 88), "Qualitative studies try to understand or describe a specific phenomena rather than to draw statistical generalizations. Therefore, it is important that the right people will be chosen to study, the most important, interviewees have to have fundamental knowledge about the research phenomena or have experience about them." Because of that, all interviewees were chosen intentionally. The interviews try to examine organisational strengths, weaknesses, opportunities and strengths. 


\subsection{Data collection}

The author used focused interviews as the qualitative research method. Data was collected through individual interviews, which means the author interviews all interviewees individually and separately. All interviews were conducted face-to-face and the duration of the interviews was approximately 60 minutes. Interviews were done within a one-week period of time and all selected interviewees were contacted one week before the actual meeting to ask their willingness to participate in the research. The author sent all selected respondents a letter (Appendix 1) beforehand and contacted them by phone afterwards to ask their willingness to participate. All selected respondents agreed to participate in the research and they we asked in advance if it would be acceptable to record interviews and they were informed the interview would take approximately 60 minutes. All interviewees were enthusiastic about the research as they all find the case company as their substantial partner; therefore, they were willing to participate in order to gain mutual benefits found in the research.

Focused interviews were used as a technique to collect qualitative data for the research. In order to be effective, focused interviews depend greatly on the interviewer's communication skills. The interviewer has to be able to build a positive rapport with the respondents, in order to make the respondents feel comfortable to express their opinion and thoughts freely on a particular subject. When respondents feel comfortable and trusted, they feel positive telling about negative and deeper thoughts. The advantages of focused interviews are efficiency and practicality and subjects can be covered in detail and in depth. Focused interviews are good in situations where the subject is not well known and the interviewer does not know the scope of answers in advance. The main advantage of interviews is its flexibility to collect data and to cover new areas of the subject. (Hirsjärvi et al. 1997 pp. 200-205.). 
Author set a meeting with 6 respondents in order to let respondents share their views about subjects the author wanted to explore and to focus on. All interviews were done individually. The objective of the interviews is to understand the respondent's point of view rather than make generalizations about behaviour. Therefore, semistructured and open-ended questions were used. Semi-structured interviews proceed rather like a normal conversation but have a specific purpose: main subjects are decided in advance but there is no systematic form of questioning or precise questions predetermined, which enables interviewer to ask further questions to open answers if needed. Interviews are good to begin with general questions about the subject and get into more details along the interview. This is especially important when interviewer and interviewee do not know each other well in order to get a relaxed atmosphere for interview. (Grönfors 1985 pp. 105-112).

All interviews were recorded. This method of documenting interviews enables the author to concentrate on the dynamics of interview rather than writing down all the answers, which could have been distracting during the actual interview and there would have been a risk of missing part of the message. Another advantage of using voice recorder is that it allows the author to re-listen an authentic situation as many times as necessary, which can reveal more than mere words can convey, taking into account descriptive words and tone of the voice. (Kananen 2011 p. 56).

\subsection{Interview form}

The main topics of interview questions were thought carefully in advance and they were tested with a person working for the case company before interviews took place. The author used semi-constructed questions, thus, interviews do not follow precise interview questions. Questions were constructed in cooperation with the CEO of the case company in order to explore the right phenomena. The CEO of the case company gave suggestions to areas that the case company would want to have a deeper understanding. 
The frame for the interview was simple and the main interview questions were decided in advance, however, enough space and flexibility were left for additional questions.

\subsection{Data processing}

After each interview the author transcribed all interviews. Transcribing refers to converting various kinds of recordings into a document that can be managed manually, or electronically with various kinds of analysis methods. There are different levels of transcribing, ranging from word-to-word reproduction to extracting core messages. The author used word-to-word transcription. This way of converting records into documents is the most accurate; therefore it demands a lot of work and is extremely time consuming. On the other hand, word-to word-expressions can be used in the final report as quotations and therefore it is a useful method. In this documentation the author did not use special notations to mark pauses or gestures, this level of documentation is not needed for the thesis. A one-hour interview takes approximately 4-6 hours of transcription work. (Kananen 2011 p. 57).

\subsection{Reliability and validity}

According to Kananen (2011 p. 66), "Reliability refers to the consistency and repeatability of the measurement and research results, for example, if the research is repeated, the results will be the same". Reliability refers to finding out if there are some random factors affecting research results, and therefore, research results could be inaccurate.

High reliability is always aimed for in all research; otherwise research can be unreliable and unjustified. Reliability is not as easily applicable to qualitative research as it 
is to quantitative research. This is because in qualitative research individuals will be the objects and the behaviour of human beings is not always rational and systematic, therefore, there can exist randomness among results. Among others, respondent's moods, physical conditions etc. can affect results. There are many other factors that can influence results including the positions of interviewer and interviewee, respondent's suitability to research, there could be misunderstandings of questions or interviewer can be too persuasive and leading. (Kananen 2011 p. 66).

The author considers that she was able to create a comfortable atmosphere during interviews making it easier to have conversations with respondents. The author was positively surprised how openly respondents shared their opinions about topics and even negative aspects were shared openly. The author has been in contact with respondents in her job before the research, which was seen as a beneficial factor for interview outcome and for professional discussions. The author's experience in the case company and overall industry helped the author perform good questions about research phenomena, which has an essential affect on research results. However, the author will take into account her job position and her personal relationship to the case company as factors that can affect the research outcome and can weaken the research results especially the questions regarding company weaknesses. Recording and transcribing interviews will the improve research's reliability and improve the research's quality as readers and respondents have access to results, therefore, research is more transparent. (Heikkinen et al. 1999 pp. 78-82).

In qualitative research, the author can be seen as tool for collecting data. It is natural as the research process proceeds the author's understanding and interpretation skills will develop, therefore, inconsistency in data collection cannot be seen as error, instead it is something that is a natural element for qualitative research. For that reason, the author cannot achieve absolute reliability in the research but can try to control it. (Heikkinen et al. 1999 pp. 78-82).

The author considers that reliability was reached in thesis as saturation occurred among respondents' answers when collecting data through interviews. The author set the meeting at first with 6 respondents and was considering more interviewees, if 
needed. The saturation point was reached through 6 interviews and there were no need for more participants. The issue of saturation is essential to qualitative research. Saturation means that similar answers occurred during different interviews, therefore, it would not have been useful to have greater number of respondents to be interviewed, as all received answers would have been repeated one after another. Saturation point will be reached when answers start to repeat themself and there is no need to have more interviews, as no new information will be brought to the study. (Kananen 2011 p. 68).

Validity means truthfulness and qualification of the research. Validity measures whether the research answers the intended questions or not, in another words, has the author been examining the right things. The concept of validity is based on how parallel arguments and reality relate to each other. In order to result in valid claims the following conditions should be met; researcher has several exemplary examples to report, there will be original documents to present and there will be solid arguments for instances used in report. (Silverman 2005 p. 211, p. 224). By selecting suitable respondents to interviews can be seen as improving research validity. 


\section{RESEARCH RESULTS}

The interview form will be found in the appendices (Appendix 2). Interviews were conducted in Finnish, as it is the mother language for all respondents and the author; thus, it was more natural for respondents to give deeper and descriptive analysis about the researched phenomena. The interview form and transcriptions are in Finnish. The interview structure is divided into four main categories. The main objectives for the interviews were to find out the current status of company's internal strengths and weaknesses and to identify possible external opportunities and threats that firm might be confronted with in the future.

There were 6 respondents to the interview. All interviews were conducted individually. A table below presents general details about respondents. All respondents have similar job title and they are all men. All companies are represented nation wide in Finland and their main headquarters are located in the capital region. Four companies have business activities outside Finland as well and two of the respondents represent a multinational company.

\begin{tabular}{|l|l|l|l|}
\hline Gender & $\begin{array}{l}\text { Duration of cooperation } \\
\text { between respondent and } \\
\text { case company (y) }\end{array}$ & $\begin{array}{l}\text { Duration of cooperation be- } \\
\text { tween companies (y) }\end{array}$ & Job Title \\
\hline Male & 2 & & Key Account Manager \\
\hline Male & & & Key Account Manager \\
\hline Male & & & Key Account Manager \\
\hline Male & & & Key Account Manager \\
\hline Male & & & Key Account Manager \\
\hline Male & & & \\
\hline
\end{tabular}

Table 1. Information about Interviewees 
In the following sections, four main interview topics and the respondents' answers will be presented. Each section will cover the respondent's opinions and views about the topic. Addition to this, interviewee's direct quotations from the transcriptions will be used. Direct quotations will be translated from Finnish into English by the author (Appendix 3 Interview transcriptions).

\subsection{Questions regarding company strengths}

In this section respondent's views about the company's internal strengths will be presented. The following questions were presented to respondents: What are the strengths of the company? Has the company succeeded in anything? What things is the company good at? All questions can be found in the interview form (Appendix 2).

All respondents found unanimously the main strengths being the skills, knowledge and motivation of the organisation and its employees and the long profound experience in the industry. Respondents were asked what they would perceive being the main three reasons for customers purchasing the case company's services and products, the answers were straightforward. The three main answers from all respondents were; the good reputation of the company and the good perception of the brand, employees' skills and customer service in the organisation and the quality and the style of the products. These three main categories will be explored in more detail.

According to interview results, all interviewees found the personnel as one of the key strengths of the company. They described the skills, knowledge and the attitudes of the personnel towards customers as being something that the company differentiates themselves from competitors. According to respondents, customer-orientation is the key success factor in the kitchen industry, and pointed out that not all companies have comprehended it. According to interviews, personnel were described as moti- 
vated, customer-minded and having a mind-set of taking customers seriously. The overall good customer-service concept was pointed out.

I argue that the organisation has absolutely above-average personnel throughout the chain, I could imagine that someone could be even jealous about it'. (Interview 5, p.25)

'I would say that first of all products are the thing for the company, the versatility and the quality of the product range is staggering and company has good concept behind it. Secondly, company has personnel, customer-oriented sales people, who set their mind to serving customer well in a hundred per cent. Company has a rear concept so that one salesperson will manage the customer's case from the first contact until the after-sales marketing. I think that does not exist in rival firms.' (Interview 4, p.21)

This present investigation shows that all respondents regard the company's reputation in a positive way and they consider this good reputation has resulted in recommendations and a wide customer network. They point out that the company has been on the market for many decades and in order to gain that position, they have successfully achieved customers who have returned to the company when they have a need for a new purchase. Recommendations are an essential role in the industry as purchase has a long lifecycle and it will not be repurchased regularly, therefore recommendations will be an essential role. According to research, respondents do not regard the company having huge visibility nation wide, but highlights that on those market areas where company is active they are really visible in way of reputation, local awareness among customers and competitors.

'Definitely it is known as a brand, but I would say that in general not all HTH competitive advantages are well comprehended in the industry but in every conversation that I am questioned who are our customers, when I mention HTH, it will be notices as a reference to us. From customer point of you, in the market areas where company exist it is known but on the other areas national wide not as strongly'. (Interview 5, p.24)

' Company has managed to get many B2B deals, either through good connections and networking or some other things are affecting, I think this is a strength, I have notice company 
has this kind on customer channel (B2B) and it needs special ability. That is something that does not necessarily come up with other kitchen providers.' (Interview 4, p.30)

This present investigation shows the products were considered as being a company strength. Respondents value products as high quality, having different style to competitors being more oriented towards Scandinavian design and having a good pricequality relation. The product range was described as being wide and versatile to provide solutions for many different customer segments and therefore it can gain a wide customer network. Some respondents pointed out that it is not easy to segment the brand, as the brand is so different to other concepts competitors provide. This was mentioned in a positive and negative aspect. The brand recognition and the brand value were thought to be good assets for the case company.

Another key strength that respondents considered was the horizontal organisational structure. Respondents argue they have noticed, particular in this industry, the best way of gaining good results are when the entrepreneurs and owners are close to the personnel. They pointed out that there are a low number of people in the management level in the organisation compared to the number of employees. This organisational structure enables communication between personnel and management to be more proactive and gives more responsibility to individual employee without close supervision of many levels of management but still having control over the personnel. Another positive effect of the firm's organisational structure was shown to be firm's ability to be responsive to fluctuations in the external environment. The decision-making process is not slow as there are a small number of people involved. Interviews showed the firm's industry is really vulnerable to changes in the economical climate and therefore there can be huge changes in the demand and supply. Thus, it is essential company can react quickly to these changes. However, it was mentioned that the case company is not following the industry's economical cycle as strongly as the average companies in the industry. Interviewees regarded the horizontal organisation could be double-edged sword; this will be explored more under the results regarding company weaknesses. 
'In general, as I have been observing things as bystander, for an individual store it is hard to succeed if there isn't entrepreneur involved. It must be extremely good, motivated and rewarded store manager so that store will succeed. Now company has a good management in all stores, as company owners are present in stores. If company would have more stores then responsibility should be more divided, which is challenging in all firms and same problems have been seen to exist in all firms when owners are not present.' (Interview 5, p.26)

'One essential reason to survive in the market is company's ability to change and to be awake about a current situation and is able to react. Challenges will arise when company is too large and making a change or to change direction is too slow. I think this company's decision-making is in hands of small group and therefore it is easy to react when there is positive and negative action on the market.' (Interview 1, p.6)

Addition to above mention aspects, the company was regarded as well managed and an organised firm, the atmosphere was seen as positive throughout the company and personnel turnover is low which was interpreted as high personnel commitment. After-sales marketing was granted as well managed and interviewees stated without good after-sales marketing it is hard to gain recommendations and build a customer network. Networking was mentioned as one key element for the company's long existence on the market.

'Yes, networking is essential, those stores that succeed above-average stores, they receive deals automatically, they do not need to do so much for the deal when demand is constant, this position can only be gained by doing extremely hard work and finishing all cases in the end as well as possible'. (Interview 2, p.10)

\subsection{Questions regarding company weaknesses}

In this section interviewees' opinions about the company's weaknesses will be presented. The following questions were presented to interviewees: What weaknesses does the company have? What should it improve in order to be more competitive? All questions can be found in the interview form (Appendix 2). 
According to interviews, respondents did not regard any serious weaknesses that could interfere with competitive disadvantage. Interviews show the horizontal organisational structure was considered as having a positive and negative effect. The positive side of organisational structure was covered in the above section. Results show that the negative side of the organisational structure was perceived as being tight control of the company owners. As mentioned above, respondents view the good side as owners have control what is happening in the organisation ensuring the right things are done in a correct way and they can assist personnel achieving intended goals. On the other hand, according to interviews it can prevent employees gaining more responsibility if it is not managed well and if there is not active communication about the employee needs for further responsibility, which is something the company has to be aware. Another issue regarding flat organisation structure that was mentioned was the heavy workload on the people in the management positions. There are only a few persons at the management level in the organisation, therefore, it is important to secure the mental and physical endurance of these people involved with many essential organisational tasks. Addition to this, respondents pointed out that as the organisation is in hands of small group, if something unexpected would happen to these people, then it would set challenges and threats for the whole company.

'Organisation is as active and vital as the owners in the flat organisations, it can be hard for owners, but being an entrepreneur is a choice of freedom'. (Interview 5, p.27)

This present investigation reveals the following opinions regarding the cooperation between respondents and the case company. The case company is an essential client for all respondents but they viewed that things could be done more efficient and with more effective cooperation. They stated the current situation is that the case company sells the clients products well, but there could be more open conversations how to make more efficient and effective cooperation. One respondent describes the current situation as following:

I have a view that the company is similar like our company in the way that it wants to do independent decisions and choices and does not want to cling to anyone instead it wants to 
be as independent as possible. Company, like us as well, we want to lead ourselves from inside the company and we have not been leaning on external forces'. (Interview 2, p.12)

Some respondents claim that it is not easy to position brand in any specific segment. This was regarded as strength as well a weakness. Respondents supporting it as a positive factor argues that it can serve many customers as company has good concept and the products are more completed to end consumer compered to competitors. The company's overall concept combines many separate attributes that are considered as competitor's individual positive factors and, therefore, the company has special concept. However, respondents say that not all the advantages that the brand has, have not been able to be understood in the market. Respondents view the brand concept different to others regarding the logistical aspect and customer-service attributes. Interviewees argue that if these attributes could be better delivered to customers, the company could gain better results.

According to investigation, another improvement point was that showrooms could be more proactive in the form of providing more input for the customers visiting stores. They highlighted that kitchen suppliers are special showrooms that can use facilities as a way of differentiation. They also suggested that through this improvement stores could end up in higher sales figures and sales of bigger entities. Improvement ideas include theme evenings at store, more passive knowledge for customers in the form of information material in showrooms.

\subsection{Questions regarding company opportunities}

In this section interviewee's opinions about the company's opportunities will be presented. The following questions were presented to interviewees: Will the industry be confronted with changes in the near future? What factors will affect the company? How will the economical situation affect the industry? How will customer behaviour affect the case company and industry? All questions can be found in the interview form (Appendix 2). 
A majority of respondents stated that the Internet would be an important factor affecting the industry in near future even more. According to research, the kitchen industry has not been confronted yet with direct kitchen sales, as for example many retail products have, but companies should be prepared to support demand for direct online kitchen sales. Research shows that direct kitchen sales differ from other retail sales, as kitchens are more complicated and bigger entities and respondents do not regard direct kitchen sales yet as an important factor. According to respondents, however, all the time an increasingly number of customers is doing firstly comparing companies on the Internet before entering the stores. The Internet will provide an attractive source for information and inspirations. After the first explorations on the Internet, customers will choose which companies it will select to visit leading to business opportunities. Interviews show the importance for companies to be active on Internet and to have attractive websites to attract customers, otherwise customers will not even visit stores and the customer is lost in the battle on the Internet. For the case company the Internet can be an opportunity to distinguish itself from competitors. The case company has a big brand behind it for support and has huge resources to be used for the Internet compared to smaller brands.

'Present customer does pre-work on the Internet, if we take customers in their thirties, when their buy an own house or apartment and will renew a kitchen, they will use Google as a search tool for different kitchen suppliers and possibly use different chat forums. The first impression will be formed even before entering the store. Experiences from relatives are important but Google is essential.' (Interview 6, p.32)

An interview question regarding the industry revealed the current status of customer service and sales personnel in the industry. Respondents did not perceive customer service and salespeople in a great way. They pointed out that the industry could be divided into two different categories. There are really well-performing companies with great sales personnel who serve their customers well and another category comprised of companies who do not have customer-orientation on their mind. Respondents argued that the success depends on how motivated and professional sales per- 
sonnel are. They pointed out that personnel turnover is high in the industry and therefore there are huge differences in professional skills between companies. Results show that respondents view the case company's customer-service level and personnel in a positive way and they regarded the case company's employee turnover as lesser than the average in the industry.

'We have received feedback, in general, that there is wrong kind of attitude among sales people. For example, when entering store, personnel should have the first 5 minutes time to listen customer and his needs. Now, we have received feedback that customers have been visiting stores without nobody recognising them, the game is lost already here. '(Interview 3 , p.15)

Several participants in the study expressed that there would be some changes in customer behaviour. According to interviewees, customers want to purchase bigger entities from the same place while saving time and providing a more pleasant shopping experience by giving responsibility to expertise rather than taking whole responsibility of purchase to themselves. Respondents argue this will be a future trend. Study expressed that another behavioural change would be that customers will be more quality and price conscious. This present investigation shows that respondents find decorating at home and paying more attention to home amusement will be a future trend. Respondents view there is a tendency to give more value to professionals who can assist to solve customer's problems and to be involved with their projects. This requires skilled sales personnel to provide individual solution for customers.

'I think that selling whole entities will be more common in the future, people has lesser and lesser time and they want to buy everything from the same place'. (Interview 1 p.6)

II think more than customers getting all products from the same place, they need a person who has this ability to see what customer needs, to take example these interior designing programmes on TV, I do not have opinion are they good or not, but clearly people are ready to pay for a person who can be involved with customer's project and their minds, what they need and where to get them'. (Interview 2, p.11) 
'I believe people have a basic need to associate with one person and one place, that could handle a bigger entity and in that way can save consumer's time and mistakes.' (Interview 2, p.12)

When respondents were questioned about other possible opportunities for the case company, two out of six considered possible expansions to be in the capital region and Russia. These respondents claimed that company has good locations in capital region already, so it could have space for one showroom more. Addition to capital region, expansion to Russian market was considered to be a potential option. The company has a showroom in Lappeenranta where there is a lot of Russian immigrants and Russian tourists, which was considered as being a potential source for Russian sales. This would require a Russian-speaking employee to enable to work effectively.

\subsection{Questions regarding company threats}

In this section interviewee's opinions about the company's threats will be presented. The following questions were presented to interviewees: Will the industry be confronted with changes in the near future? What is the situation with supply and demand in the industry? Will the economical situation affect industry? Will customer behaviour be seen to affect the case company and industry? All questions can be found in the interview form (Appendix 2).

According to research results, the company's industry is highly competitive. There is a lot of competition and some respondents describe the industry as having excess supply. The industry has many suppliers and respondents argue that currently domestic factories are run by under capacity, which has lead to intensive price competition. All interviewees say price competition is strong in the industry and argue that companies cannot have low price as the only key factor as there will always be in the market a company who can have a lower price. Some respondents argue that there are so-called price terrorists on the mar- ket that will aggressively market only the 
low price, which will harm the overall industry.

'Price competition is so severe that low-price segment has been intervened by one big Swedish brand (Ikea). I have noticed that typical low-price brands have been forced to upgrade their profile, otherwise they could not compete with this the lowest price provider, so price competition is tough.' (Interview 2, p.11)

A majority of respondents mentioned that the industry is largely dependent on the general economical cycle. They regard the products company is selling not as a necessity; there is rarely an occasion where a consumer is without kitchen. The nature of the purchase is something where people have to save money or alternatively take a loan; therefore, when there is an economical slowdown many private investments will be frozen until the fluctuations will be balanced. Therefore renovations and overall new building projects can be postponed into the future after recessions are overcome, which will constrain overall demand in the industry and can lead to excess supply and stronger competition for customers.

Most of those interviewed stated differentiation as the only way of survival; price competition is hard for a long period of time and will be an endless battle. According to respondents, companies have to be able to provide customers something different, some other values other than low price in order to be competitive. When a company can provide some additional value, during the difficult economical times, the company can maintain its position, as it is not so dependent on the price.

'Those who have been doing well, they have also differentiated and concentrated on their own products and on their own strengths. And one important thing is networking, if one is new on the business-field it takes two years trusting that business will start to grow little by little and it takes hard local work to do.' (Interview 2, p.10)

Because there are many suppliers in the market, results show concern towards segmentation and differentiation of brands. Respondents have concerns towards customer's ability to differentiate different brands. Respondents pointed out that low price 
segmented firms market their products as quality kitchen providers, which can confuse customers when comparing products. Four respondents out of six said there are many similar brands in the same segment with the case company providing similar products with a similar price level.

This present investigation shows another threat was thought to be changes in customer behaviour. Most of the respondents thought there would be change in behaviour towards demand for professionals, higher customer service and quality products, but few respondents regarded the opposite consumer behaviour. These respondents took customer behaviour pattern in Sweden as an example. They argue that Finnish consumers have traditionally been following the patterns of Swedish consumer behaviour. The Swedish trend has had a behaviour change in demand towards products with a shorter lifetime span. According to respondents, this trend has been favouring products with lower price and shorter lifecycle. The demand towards cheaper low quality products was regarded as threat factor for the case company. The current trend in Sweden, according to two respondents, follows the trend were consumers do not want to make purchases with a long time perspective, instead they will be more short-sighted when decisions are made concerning products like the case company is selling. Some respondents considered hypermarkets being a threat for the company, as they view customers wanting to buy everything from the same place and they thought small-specialised stores could not compete with hypermarkets that can provide everything to the end consumer.

\subsection{SWOT analysis}

In the above sections respondent's opinions and understanding about the company's strengths, weaknesses, opportunities and threats were presented. The author has made a SWOT analysis based on these answers (found below in table 2). Kamensky (2000 p.39) refers to analysis' importance to companies as 'analysis will formulate the important base on which successful business can be build on'. Analysis can be 
divided in two different parts as external and internal analysis. Here SWOT analysis will cover $t$ both those parts in a synthetic way combining the present time and the future, which can describe the company's current state and the future possibilities. 


\begin{tabular}{|c|c|}
\hline Strengths (Internal environment) & Weaknesses (Internal environment) \\
\hline $\begin{array}{ll}\text { - } & \text { Skilled and customer-oriented } \\
\text { - } & \text { Lowployees } \\
\text { - } & \text { Horizontal organisational structure } \\
& \text { and owners close to personnel } \\
\text { - } & \text { Good brand image and reputation } \\
\text { - } & \text { Wide product range } \\
\text { - } & \text { Product's good price-quality relationship } \\
\text { - } & \text { Industry experience } \\
\text { - } & \text { Company values } \\
\text { - } & \text { Important client for suppliers } \\
\text { - } & \text { Abilities in B2B } \\
\text { - } & \text { Recommendation and } \\
& \text { Customer network } \\
\text { - } & \text { High employee involvement } \\
\text { - } & \text { Strong local visibility } \\
\text { - } & \text { Brand segmentation }\end{array}$ & $\begin{array}{ll}\text { - } & \text { Horizontal organisation structure } \\
\text { - } & \text { Showroom activity } \\
\text { - } & \text { parttle cooperation between } \\
\text { - } & \text { Brand segmentation } \\
\text { - } & \text { Sales of bigger entities } \\
\text { - } & \text { Ability to change overtime } \\
\text { - } & \text { Nation wide brand recognition not as } \\
\text { strong as competitors } \\
\text { - Not as strong brand support as most } \\
\text { competitors }\end{array}$ \\
\hline Opportunities (External environment) & Threats (External environment) \\
\hline $\begin{array}{l}\text { - } \quad \text { Change in customer behaviour towards } \\
\text { services } \\
\text { - } \quad \text { Increase in Internet usage } \\
\text { - } \quad \text { Current status of customer service } \\
\text { In industry } \\
\text { - } \quad \text { Lack of professional personnel } \\
\text { In the market } \\
\text { - Expansions }\end{array}$ & $\begin{array}{ll}- & \text { Strong competition } \\
- & \text { Strong price competition } \\
- & \text { Excess supply in the market } \\
\text { - } & \text { Economical situation } \\
- & \text { Decrease in construction industry } \\
- & \text { Change in customer behaviour } \\
- & \text { Internet sales } \\
- & \text { Technological development } \\
- & \text { Hypermarkets } \\
- & \text { Low barrier to entry to market }\end{array}$ \\
\hline
\end{tabular}

Table 2. SWOT analysis - case company 


\section{$5 \quad$ DISCUSSION AND FINDINGS}

This research aims at finding out the factors in the company's internal and external environment that will affect the company's performance and competitiveness.

The research tries to find out answers to the questions: What is the current state of the case company's internal and external environment? What strategic recommendations can be made to the company based on these findings? The author has conducted SWOT analysis based on research results and will provide the case company strategic recommendations based on SWOT analysis and research results. By following these recommendations, the company can strengthen its competitiveness and can prepare itself for future challenges.

According to Porter (1985 p.54), although companies within the same industry can be perceived to have similar value chains, the rival companies usually have different value chains. This means that companies will perform similar things in the different way. Research reveals that the case company has succeeded doing some things differently to its rival firms, for example it has gained abilities in B2B segment, reputation and a wide customer network. These differences between the value chains can create a source for competitive advantage and increase company's competitiveness.

According to research, four respondents out of six consider that the company has acquired substantial experience with project segment. The company has succeeded in winning many high-end B2B projects, which has been mentioned as something extraordinary as not many private dealers have the resources to carry out projects of this scale. Instead, B2B projects have usually been carried out through factories' own project departments, not by individual dealers. One big Finnish company who can compete with low prices is dominating the market in B2B projects. However, respondents think the case company has a special ability to get B2B deals, either through personal connections or special capabilities in this segment. According to Kamensky (2000 p.171), organisations should try to strengthen, further improve and take advantage of its strengths and opportunities. When a company concentrates on these attributes and functions it can gain a better performance over its competi- 
tors. B2B is currently a relatively small segment inside the company's customer segments. This segment could provide profitable opportunities; therefore, the company could give more focus on this segment. According to the CEO of the case company, the company has 17 employees with 3-4 of them currently working in this segment and these people are working over their capacity. Currently the company is concentrating more on $\mathrm{B} 2 \mathrm{C}$ segment but the company could expand their focus on B2B segment. This concentration would require having more people to work on the B2B segment as the company's current resources are fully utilized. Employees new to the B2B segment would need an education to meet the requirements of this field as it has different characters to the B2C segment. The company could further research whether there could be the potential to expand this segment and how they would handle the increased amount of B2B projects. Increasing the collaboration with existing B2B partners or acquiring new B2B partners could aid this development.

Another result regarding the company's strengths was considered to be the owner's proximity to personnel. According to research, it is vital for showroom's success to have the owners highly involved with personnel in daily activities. Respondents appreciated this as one of the key strengths. On the other hand, horizontal organisation structure can constrain a company in the long run as there are a small amount of people in the management position and the company is heavily reliant on small group of core people. The company has expanded its business during the last two years; as a result the amount of employees increased from 10 to 17 employees. As a result of this expansion, the company has introduced a new level of management and divided the responsibility to store managers. It is essential for the company's continuity and for owner's durability to push some responsibility to different management levels in the organisation. This new level of management can be considered to be a threat factor, if it does not work effectively. The introduction of this new management level is relatively new. Therefore, the company has to work effectively to get this cooperation to work as intended. The company is on the right way in sharing responsibility, in order to work more effectively and efficiently and it will be prepared if something unexpected happens to higher management. This kind of organisational change is not easy for a company where the owners have previously been responsible for 
everything. For the future, the company should try to get these employees new to management positions, to take responsibility for the tasks intended for them. In order to work effectively, the company should research whether all the new people in management positions are aware of their new tasks that they are responsible for and are they capable of performing these tasks. Equally, the important question is whether the owners of the company know what they expect from this new level of management and does this correspond with the expectations of the new managers. For the company to work effectively and to get new organisational structure to succeed, all employees and owners should have clear task division, in order to be able to achieve the desired goals. The company should investigate the state of this cooperation internally and act on further findings.

The investigation results shows that four respondents out of six, think there will be a shift in the consumer behaviour towards more services. This present investigation shows respondents regard consumers appreciating more professional personnel who can assist them to make the right decisions and find solutions for their needs, while customers can save money and avoid wrong purchases. This change in consumer behaviour will present an opportunity to the company as research reveals knowledge and customer service of company's personnel is positioned above the industry average. The company's current strengths will align with this possible change in customer behaviour. According to Hitt et al. (2007 p. 71), external environments can create opportunities and threats for a firm but internal environmental conditions can turn these opportunities and threats to competitive advantage by using the organisation's capabilities, unique resources and core competencies. The company should further educate their personnel to have the leading edge in innovative news on the market and to educate staff to improve their customer service quality. According to Barney (2007 p.17), a firm has a competitive advantage when it is able to create more economic value than rival firms. Porter (2006 pp. 74-77) argues that the company can create higher economic value either through differentiation or cost advantage. According to Porter's definition, differentiation means the capability to provide customers superior and special value in the form of product's special features and quality, or in the form of aftersales customer service (Porter 2006 pp. 74-77). The company 
should hold regular sales and product education for their staff. Every time when something new is launched in the market, it has to be presented to whole company. The company should regularly monitor staff's knowledge and provide further education when required. Today, the company's concept is already service-oriented, as the company provides consultation at a customer's home and also creates designs for customers for free of charge. Today, the company holds training for the all staff at the same time; however, the company has employees with different levels of knowledge. In the future, education could be more specific to employees with the same knowledge and have a more individualistic perspective. There must also be an effective follow-up in order to be beneficial. The company should aim to be acknowledged for its upfront knowledge about the industry and excellent customer service and achieve to gain its strategic position thorough differentiation.

This presents study predicts that there will be a shift towards more demand in services; therefore the case company has to be prepared to meet these demands. According to Porter (1985 pp. 54-60), a company's value chain is based on different organisational functions that help a product to move along the chain passing different stages starting from raw material stage to final customer stage. Every part of the value chain will increase the value of the final product. Today, the company provides additional installation services for its customers. Customers either install products by themselves, hire their own renovation team or customers use the case company's installation service. The CEO of the company says they have confronted similar experiences about the increase in demand for services. Stores located in the capital region have especially experienced an increase in demand for installation services and supporting services such as plumbing and electricity work. External companies represent the case company when they carry out these additional services. These additional services have an essential effect on how the end customer experiences the whole purchase. It is important that the case company has well performing partners as they are part of case company's value system and they have essential effect on how satisfied the end customers are. Porter (1985 pp. 70-73) describes the value system as integration of supplier's, firm's, distribution channels and the buyer's value chains. These linkages behave in a similar way as the different functions inside an organiza- 
tion; therefore, all value chains in the value system have an influence on the organisation's costs and differentiation. The case company could develop this cooperation even more to ensure that these external companies can deliver superior outcomes and ensure that the cooperation is efficient and effective. Porter (1985 pp. 70-73) emphasizes that the success of the company is dependable also on the success of the whole value system and how the end customer perceives the entire value system, not only the value chain that the company contributes. The company has stores in different cities; therefore the company has different local partners for all stores. The case company has to be prepared to meet these predicted changes in consumer behaviour and turn this opportunity into strength.

It is predicted that customers want to buy all purchases and services from the same place. Today, the company does not provide any other housing renovation services. According to research, consumers are predicted to be more willing to make all their purchases from the same place to avoid conflicts and to save time. Therefore, the company should find reliable partners who are able to do other housing renovations to serve 'turnkey' customers who want their project to be carried out by only one company. The company should turn this opportunity to satisfy the needs of the riskadverse customers. The case company should further research what is the current state of these partner companies; do they perform their tasks in the way case company requires, how successful have these current collaborations been, how satisfied are customers and could the collaboration be carried out more effectively and efficient$1 y ?$

The findings suggest a concern towards the Internet sales. Respondents did not consider direct sales affecting kitchen sales yet, but respondents agreed unanimously that the kitchen industry would definitely be confronted with Internet sales in the future. According to Kohvakka (2012), there has been a continuously increase in online shopping in Finland and the statistics during the last 6 months shows that online retailing will continue to increase. Low price, convenience and a wide product selection have been why consumers have changed from traditional shopping to 
online shopping (TNS Gallup 2011). Research results show that Internet sales have influenced the kitchen appliance market. The case company should be prepared to act on this phenomenon, as appliance sales are an important by-product for the company's sales. The case company should comprehensively aim at focusing in all areas and to be acknowledged as a specialist in its own market. The company should try to provide customers more than they can gain and benefit from online sales or in appliance stores. This means personnel have to have a wide knowledge about appliances that they can show in the real kitchen environment in the showrooms and assist customers choosing the right products for their needs. The threat arises if customers cannot benefit from the traditional way of shopping they will change to online shopping to get a lower price, unless other benefits can be delivered to them. The company should research what the current state of appliance sales is today and how the current resources correspond with the above-mentioned recommendations and act upon them.

The Internet can present opportunities as well. Research revealed interesting opportunities to the case company, including an increase in the Internet usage as a primary search tool. Few respondent mentioned that the first battle over customers are held on the Internet as consumers will look at websites and use different social media forums to find out more about companies. If there is unfavourable information about the company or websites are not inspiring the battle is already lost. The case company should take care of its reputation in online forums.

Competition and the general economical situation can be regarded as a threat factor for almost all companies in all industries. However, they still do not reduce their influence. According to Lynch (2006 pp. 78-81), these external factors can have an enormous effect on any firm's growth and survival. Firms have to be aware of the conditions in its external environment and firms have to identify and understand the most significant threats and opportunities in its external environment that influences the company. This present investigation shows the current economical slowdown is affecting the construction industry se- verely and some respondents stated that 
many factories on the market are currently running under capacity and they are using aggressive price reductions to get orders in. The construction industry will follow the pattern of the general economical situation but it will have a slightly delayed effect on industry as projects usually take several years to finish from the initial planning to the final implementation. According to an economic review published by Rakennusteollisuus, in 2012 there will be an $8 \%$ reduction in the construction industry compared to the previous year. As a result of the unstable economical situation, many projects have been postponed for the future. This situation will affect private consumers, as they are less willing to make significant investments. However, according to an article published by Rakennusteollisuus, renovations will stay the same or even increase compared to last year. As the new building segment will be decreasing, the case company should find potential business partners in the renovation segment who could do cooperation with the case company and bring customers in this segment.

In addition to the current economical slowdown, the research reveals that the industry is highly competitive. All interviews agreed the industry has a lot of companies and few respondents claimed the industry as having excess supply. According to Hitt et al. (2007 pp. 49-53), the five forces model will assist the company to determine whether the industry is attractive and there are chances to achieve a competitive position. The industry is unattractive and it has a low potential to earn above-average returns if there are low entry barriers, buyers and suppliers have strong bargaining power, there exists intense rivalry among competitors and there will be strong competitive threat of product substitutes. This presents investigation shows concerns towards price competition in the market, as many companies are competing with low prices. Ikea's entrance to the Finnish market has made traditional low price companies upgrade their image, as they cannot anymore compete with only low prices. Respondents have concerns about customer's ability to segment different brands, including the case company, as many low segment companies try to build higher brand images in the way as the quality product providers like the case company, which can be confusing to consumers. Addition to this, research findings propose that there are many similar companies within the same price group and, therefore it is easy for customers to find substitute products. To sum up, research found out that company 
is facing a lot of competition, there are low barriers to entry and there exists a product substitutes within the same price group. Due to these conditions, buyers have a strong purchasing power.

According to Coulter (2008 pp. 4-5), in order to form a strategy, company has to make a fundamental analysis of its internal and external environment. Strategic position can be gained only through a successful strategy formulation and implementing. All the above-mentioned strengths, weaknesses, opportunities and threats will influence the case company in making its future strategic management decisions. The author has presented the main factors in the company's internal and external environment that the author regards to have significant effect on the case company's future and competitiveness. The company should do further internal research based on these recommendations to have the greatest effect on the company's performance. Based on the findings the author can draw a conclusion that the company should differentiate itself from competitors based on the author's recommendations. The company should enforce its image to be renowned for being pioneer in customer service and an overall specialist in its own market. By following the author's recommendations and the suggested further research, the company should be able to achieve this aim.

The author has gained significant amount of information during this thesis process. She has learned a lot about the case company and the overall industry. The empirical part resulted in acquiring a lot of useful information that the author could not expect to be gained. All results could not be used for this thesis as interviews produced so much potential material that the author had to select the most essential factors affecting company's performance and competitiveness. This process has given the author a lot of new tools for her existing job in the case company. The main research results have been introduced to the $\mathrm{CEO}$ of the case company. The writer continues working for the case company and has agreed with the CEO that during the beginning of the next year, she will begin further internal research on the main recommendation topics in order to gain the greatest outcome of results gained from this thesis. All the results 
and the plan for the further research will be presented to the whole company. 


\section{CONCLUSION}

As the business environment frequently changes, a company should regularly analyse its internal and external environments in order to further develop its business. As the world is getting smaller and competition increases it is vital for a company's survival to regularly reassess the direction of its business. Companies cannot take its resources and capabilities for granted, as the external environment changes companies have to change too. The most significant strategic management theories are mostly under 40 years old. Strategic management is currently a relevant topic for many company leaders and managers in today's business world as companies have to be prepared to act on conditions that are evolving in a fast pace.

The research problem was to identify the strengths, weaknesses, opportunities and threats of the case company and to prepare strategic recommendations based on these findings in company's internal and external environments. The aim of the thesis was to identify the key factors that affect company's performance and competitiveness now and in the future and to provide recommendations for next steps.

Literature in strategic management was used as the theoretical framework. The empirical research was carried out through six individual focused interviews, which enabled the author to get a deeper understanding about the research phenomena and to get new ideas and perspectives for the company. Interviews gave a good impression about the state of the company's internal and external environments. Interviews produced a lot of good material, which can be utilized now and in the further studies.

I feel this thesis answered relatively well to the aimed researched questions: What is the current state of the case company's internal and external environments? What strategic recommendations can be made to the company based on these findings? I feel I was able to identify the main strengths, weaknesses, opportunities and threats that company should have a focus in the future and which will have a great effect on company's competitiveness. By following these recommendations and having a fur- 
ther internal research on them company can utilize the outcome of thesis in a greater extent. 


\section{REFERENCES}

Balance Consulting. 2012, Nopea kasvu siivitti Markkinointi Pakkaset Oy:n vahvaan nousuun. Kauppalehti. Accessed 20.10.2012. Published 14.6.2012.

http://www.kauppalehti.fi/5/i/yritykset/tulostiedote/tiedote.jsp?selected=kaikki\&oid= $20120601 / 13396851094890$

Barney, J. 2007, Gaining sustaining competitive advantage. $3^{\text {rd }}$ Edition. Prentice Hall.

Barney, J. \& Hesterley, W. 2008, Strategic Management and Competitive Advantage. Prentice Hall.

Coulter, M. 2008, Strategic management in action. $4^{\text {th }}$ Edition. Pearson Education. New Jersey. United States.

Frosterus, N. \& Roponen, S. 2011, Suomalainen verkkokauppa kasvaa ja kehittyy. TNS Gallup. Accessed 20.11.2012. Published 3.2011.

http://www.tns-gallup.fi/index.php?k=14663

Grönfors, M. 1985. Kvantitatiiviset kenttätyömenetelmät. $2^{\text {nd }}$ Edition. WSOY.

Hamel, G. \& Prahalad, C. K. 2006, Kilpajuoksu tulevasta. Original English version: Competing for the Future. Harvard Business School Press. Talentum Media Oy.

Heikkinen, H. \& Huttunen, R. \& Moilanen, P. 1999, Siinä tutkija missä tekijä. Atena Kustannus.

Hirsjärvi, S. \& Remes, P. \& Sajavaara, P. 1997, Tutki ja kirjoita. Tammer-Paino Oy. Tampere. 
Hitt, M. \& Hoskisson, R. \& Ireland, R. 2007, Management of Strategy. Thomson South-Western. International Student Edition.

Kamansky, M. 2000, Strateginen johtaminen. Gummerus Kirjapaino Oy. Jyväskylä.

Kananen, J. 2011, Rafting Through the Thesis Process. JAMK University of Applied Sciences. Jyväskylä.

Kehusmaa, K. 2012, Strategiatyö - Organisaation voimalähde. Helsingin seudun kauppakamari / Helsingin Kamari Oy.

Lindroos, J.E. \& Lohivesi, K. 2006, Onnistu Strategiassa. $2^{\text {nd }}$ Edition. WSOY.

Lynch, R. 2006, Corporate Strategy. $4^{\text {th }}$ edition. Prentice Hall.

Porter, M. 1985, Kilpailuetu. Original English version: Competitive Advantage Creating and Sustaining Superior Performance. $3^{\text {rd }}$ Edition. Weilin + Gööss.

Porter, M. 2006, Kansakuntien kilpailuetu. Original English version: The Competitive Advantage of Nations. $2^{\text {nd }}$ Edition. Sane Töregård Agency Ab.

Rakennusteollisuus. Rakennusteollisuus RT:n suhdannekatsaus. Accessed. 19.11.2012. Published April 2012.

http://www.google.com/url?sa=t\&rct=j\&q=uudisrakentaminen\%20ennuste\&source= web\&cd $=3 \& \mathrm{cad}=\mathrm{rja} \& \mathrm{ved}=0 \mathrm{CEQQFj} \mathrm{AC} \& \mathrm{url}=\mathrm{http} \% 3 \mathrm{~A} \% 2 \mathrm{~F} \% 2 \mathrm{Fwww}$. rakennusteoll isuus.fi\%2Fdownload.aspx\%3FintFileID\%3D2999\%26intLinkedFromObjectID\%3D 9288\&ei=ggitUMDrJ8rZtAbH44DwBQ\&usg=AFQjCNHVQYf_Zk1YMwguWvMO $5 q$ SKBjDIgg 
Rissanen, T. 2007, Kilpailu markkinoilla. Kustannusyhtiö Pohjantähti. Vaasa.

Silverman, D. 2005, Doing Qualitative Research. $2^{\text {nd }}$ Edition. Sage Publications Ltd. London.

Tuomi, J. \& Sarajärvi, A. 2002, Laadullinen tutkimus ja sisällönanalyysi. Tammi. Helsinki.

Worthington, I. \& Britton, C. 2009, The Business Environment. $6^{\text {th }}$ Edition. Pearson Education Limited. Great Britain.

Zimmerer, T. \& Scarborough, N. 2002, Essentials of Entrepreneurship and Small Business Management. $3^{\text {rd }}$ Edition. Pearson Education. New Jersey. United States. 


\section{APPENDICES}

Appendix $1 \quad$ Letter to respondents

Hei,

Suoritan opinnäytetyöhöni liittyvää tutkimusta, jonka toimeksiantajana toimii Markkinointi Pakkaset Oy. Tutkimuksen tavoitteena on löytää Markkinointi Pakkaset Oy:lle kehitysideoita liittyen yrityksen liiketoiminnan edistämiseen. Tämän haastattelun tavoitteena on kartoittaa yrityksen nykyistä sisäistä toimintaympäristöä sekä ulkoisen toimintaympäristön luomia mahdollisuuksia ja haasteita.

Teidät on valittu tutkimukseen, koska toimitte yritykselle tärkeänä yhteistyökumppanina ja teillä on laaja ja vankka tuntemus yrityksestä ja yrityksen toimialasta ja markkinatilanteesta. Tutkimus on erittäin merkityksellinen yritykselle, sillä tämän kaltaista tutkimusta ei ole aiemmin toteutettu.

Olisin kiitollinen, jos olisitte halukkaita ottamaan osaa tutkimukseen. Tutkimuksen kehitysideat auttavat toimeksiantajaa kehittämään liiketoimintaansa ja samalla toimimaan teille mahdollisimman tuottoisana ja parempana yhteistyökumppanina.

Käsittelen kaikki vastaukset luottamuksellisesti, vastanneiden eikä yrityksen nimiä mainita tutkimuksessa. Jos ette koe olevanne oikea henkilö vastaamaan tähän haastatteluun ja tiedätte organisaatiossanne sopivamman henkilön, voisitteko ystävällisesti välittää tämän viestin eteenpäin? Kiitos.

Kiitos etukäteen, olen teihin yhteydessä puhelimitse lähiaikoina!

Ystävällisin terveisin

Tia-Maria Pakkanen 
Appendix 2 Interview form

Aluksi haastattelija kiittää vastaajaa tutkimukseen osallistumisesta ja kertoo millainen merkitys tutkimuksella on toimeksiantajalleen sekä vastanneille.

Haastattelija kertoo vastaajalle että haastattelut nauhoitetaan ja että vastaukset käydään lävitse luottamuksellisesti eikä vastanneiden ja yritysten nimiä mainita tutkimuksessa.

Tausta tietoja:

Kuinka kauan yrityksenne on toiminut yhteistyössä Markkinointi Pakkaset Oy:n kanssa?

Kuinka kauan olette itse olleet yhteistyössä MP Oy:n kanssa?

Millä perustein yrityksenne on valinnut MP Oy:n yhteistyökumppaniksi?

Miten näette MP Oy:n aseman omalla alallaan?

Ketä kilpailijoita segmentoisitte yrityksen kanssa samaan kategoriaan?

Minkälaisena yhteistyökumppanina koet MP Oy:n olevan teidän yrityksellenne?

Millaisena koette MP Oy:n HTH:n jälleenmyyjänä?

Yrityksen sisäinen toimintaympäristö- vahvuudet:

Minkä luulette olevan kolme tärkeintä syytä miksi kuluttaja päätyy ostamaan MP Oy:n palveluita? Perustelisitko vastauksesi.

Koetko MP Oy:lla olevan erityisosaamista kilpailijoihin nähden? Jos on, minkälaista? Entä erottavia tekijöitä?

Missä asioissa yritys on mielestänne onnistunut?

Minkälainen on yrityksen luoma mielikuva ammattiosaamisesta? 
Kohtaavatko yrityksen luoma mielikuva ja yrityksen henkilökunosaami nen/palvelutaso toisiaan? Perustelisitteko vastauksenne.

Millaisena koet toimialan yritysten ammattitaidon/ asiakaspalvelun tason?

Eroaako yrityksen palvelukonsepti kilpailijoistaan?

Miten yritys voisi kehittää toimintaansa paremmaksi?

Yrityksen sisäinen toimintaympäristö- heikkoudet:

Minkälaisia kehityskohtia koet yrityksellä olevan, joita tulisi kehittää?

Miten kuvailisit seuraavia kohtia:

1.1 Organisaatio

1.2 Henkilökunta

1.3 Asiakaspalvelu

1.4 Tuotteet

Mitkä tekijöitä tulisi muuttaa, jotta yritys voisi kasvaa tulevaisuudessa?

Minkä kohdan koet olevan yrityksen heikoin lenkki, jota tulisi kehittää?

Yrityksen ulkoinen toimintaympäristö - Mahdollisuudet/ Uhkat

Tuleeko alalle helposti uusia kilpailijoita?

Minkälaisena koet kilpailun olevan alalla?

Miten taloudellinen tilanne (suhdannevaihtelut) vaikuttavat toimialaan?

Miten koet suhdannevaihteluiden vaikuttavan MP Oy:n toimintaan?

Mitkä tekijät tulevat muokkaamaan toimialaa tulevaisuudessa? Ja miten? ( tulostaso, sukupolven vaihdos, trendit)

Mitä aivan uusia toimintoja tai tekijöitä tulisi luoda, joita toimialalla ei ole aiemmin tarjottu?

Minkälaisia mahdollisuuksia näet yrityksellä tulevaisuudessa? / Entä uhkia? 